Anatolian Journal of Instruction

\title{
CRITICAL THINKING SKILLS USED AMONG UNIVERSITY STUDENTS IN READING COMPREHENSION
}

\author{
Asnawi Muslem* (corresponding author) \\ English Education Study Program, Faculty of Teacher Training and Education, Syiah \\ Kuala University, Indonesia. \\ Email: drasnawi@unsyiah.ac.id \\ Bustami Usman** \\ English Education Study Program, Faculty of Teacher Training and Education, Syiah \\ Kuala University, Indonesia \\ bustami55@yahoo.com \\ Siti Sarah Fitriani $* * *$ \\ English Education Study Program, Faculty of Teacher Training and Education, Syiah \\ Kuala University, Indonesia. \\ Email: ssfitriani@gmail.com \\ Nidar Velayati $* * * *$ \\ English Education Study Program, Faculty of Teacher Training and Education, Syiah \\ Kuala University, Indonesia. \\ Email: just_velayati@yahoo.com
}

\begin{abstract}
The objective of this study was to investigate the frequencies of using critical thinking in reading among university students namely; interpretation, analysis, evaluation, inference, explanation, and self-regulation. The quantitative method was used in this study. The respondents of this study were 100 second year undergraduate students of Ar-raniry State Islamic University, Banda Aceh. The data needed for the study were collected through a set of questionnaire. The data collected were analyzed quantitatively in the form of percentages. The results showed that inference was the critical thinking skill mostly about $54 \%$ of students used in reading comprehension. In addition, the next types of critical thinking skills used by students in order were analysis, explanation, evaluation, interpretation, and self-regulation. Self-regulation was the least skill about $5 \%$ of them practised by students in reading comprehension. It indicated that the frequency of using critical thinking skills among university students were more on inference level in reading comprehension.
\end{abstract}

Key words: Critical thinking skill, university student, reading comprehension

\section{Introduction}

Indonesia is one of the countries in the world that teaches English subject as a foreign language to all level of education. English is taught from Junior High School to higher 
education level (university). The focus of teaching the subject is on four skills namely; listening, speaking, reading, and writing. Reading is one of the four English skills should be taught at university level. Many things can be obtained through reading a text especially the information related to the text being read (Schultz, 1982). Through reading, a learner can generate his/her critical thinking. This skill is necessary for students since it can enrich and update their knowledge especially in English as well as their critical thinking.

Critical thinking is a cognitive activity, associated done by a learner in reading comprehension with using the mind. It means that learning to think in critically analytical and evaluative ways means using mental processes such as attention, categorization, selection, and judgment (Cottrell, 2011; Halpern, 1999). Critical thinking is a difficult process of thought that comprises a wide range of skills and attitudes. The range of the skills includes interpretation, analysis, evaluation, inference, explanation, and self-regulation (Elder \& Paul, 2001; Facione, 2006). The main goal of reading is comprehension. Comprehension in reading is needed to understand the information in the text. comprehension involves understanding the vocabulary, seeing relationships among words and concepts, organizing ideas, recognizing the author's purpose, evaluating the context, and making judgments (Barchers, 1998; Burbules \& Berk, 1999; Chou 2011; Cottrell, 2011). In addition, comprehension in reading is focused on three levels namely; word, sentence and text (Pressley, 2006). Successful readers are able to use strategies to engage and closely think of a text for building comprehension at these three levels.

Cottrell (2011) mentions the critical thinking skills that involve namely; identifying other people's positions, arguments, and conclusions; evaluating the evidence for alternative point of view; weighing up opposing argument and evidence fairly; being able to read between the line, seeing behind surfaces and identifying false or unfair assumptions; recognizing technique used to make certain position more appealing than others; reflecting on issues in a structured way, bringing logic and insight to bear; and drawing conclusion. That is way critical thinking is a complex activity done by reader, learner and other parties in reading comprehension. Consequently, teacher should facilitate learners to enable them use their critical thinking when reading a text. The need to facilitate learner to have critical thinking skills is to enable them solve the problem in reading comprehension (Carr, 1988). In addition, by incorporating critical thinking gives learners tools to use scepticism and doubt constructively so that they can analyze what is before them (Cottrell, 2011).

Incorporating critical thinking in reading is very important. It assists students to achieve the goal of reading, which is comprehension (Carr, 1988). This kind of thinking engages students to actively participate in a reading class. Zabihi and Pordel (2011), state several scholars believe that instructing children how to think and read critically is an important aspect of all reading programs which aim at comprehension. Kamali and Fahim (2011) also concludes that critical thinking is crucial for answering reading comprehension questions, especially those related to main ideas. Overall, reading by critically think is 
viewing the issue or information by activating readers' mind or thinking for the purpose of comprehension. Many studies have been conducted related to critical thinking and reading comprehension (Choy and Cheah, 2009; Kamali and Fahim, 2011; Putri, 2014; Jie, Yuhong and Yuan, 2014). Based on the previous explanation and studies, this study intended to investigate the frequency of using critical thinking skills in reading comprehension subject that focus on the aspect of interpretation, analysis, evaluation, inference, explanation and self-regulation at state Islamic University of Ar-Raniry, Banda Aceh.

\section{Research question}

What types of critical thinking skills are mostly used by students in reading comprehension at state Islamic University of Ar-Raniry Banda Aceh?

\section{Research objective}

The objective of this study is to investigate the most frequent used types of critical thinking skills by students in reading comprehension at state Islamic University of ArRaniry Banda Aceh.

\section{Critical Thinking}

Critical thinking is a pervasive academic literature term that is seldom clearly or comprehensively defined (Petress, 2004). However, the authors try to provide some definition of critical thinking in this study. Critical thinking is the use of those cognitive skills or strategies that increase the probability of a desirable outcome (Halpern, 2002). It means that when a learner reads a text, she/he has something in his/her mind related to what being read. Critical thinking is defined as a way of thinking by using cognitive skills which involves higher level of cognitive ability to do deep analysis, synthesis and reflection (Duron, Limbach \& Waugh, 2006; Paul, 1985). Critical thinking is also the ability to process the information by using some cognitive skills (Halpern, 1999). According to McPeck (2016) critical thinking simply refers to the careful and precise thinking that is used to resolve some problem. In this case, a learner should be able to think critically and resolve the problem in reading comprehension.

Some other definitions about critical thinking can be explained as follows: (1) the ability to analyze facts, generate and organize ideas, defend opinions, make comparisons, draw inferences, evaluate arguments and solve problems (2) a way of reasoning that demands adequate support for one's beliefs and an unwillingness to be persuaded unless support is forthcoming (3) involving analytical thinking for the purpose of evaluating what is read (4) a conscious and deliberate process which is used to interpret or evaluate information and experiences with a set of reflective attitudes and abilities that guide thoughtful beliefs and actions (5) critical thinking is active, systematic process of understanding and evaluating arguments. An argument provides an assertion about the properties of some object or the relationship between two or more 
objects and evidence to support or refute the assertion. Critical thinkers acknowledge that there is no single correct way to understand and evaluate arguments and that all attempts are not necessarily successful (6) the intellectually disciplined process of actively and skillfully conceptualizing, applying, analyzing, synthesizing, and/or evaluating information gathered from, or generated by, observation, experience, reflection, reasoning, or communication, as a guide to belief and action (7) reasonable reflective thinking focused on deciding what to believe or do (8) skillful, responsible thinking that facilitates good judgment because it (1) relies upon criteria, (2) is selfcorrecting, and (3) is sensitive to context (cited in Paul 1992). Talking about critical thinking cannot be separated from its components of it.

\section{Components in Critical Thinking}

There are six components of critical thinking which are proposed by Elder and Paul (2001). In line with their components, Facione (2006) also state that critical thinking also has six components. While, Ellis and Robinson (2008) proposed critical thinking consisted of logic, analysis, evaluation, inference, interpretation, explanation, and synthesis. Below are the explanations of each skill:

The first component stated by Elder and Paul (2001) is interpretation. Facione (2015) also includes interpretation as one of critical thinking components. Interpretation is the ability to comprehend information (Elder \& Paul, 2001). In addition, Facione (2015) mentions that interpretation is considered as comprehending and expressing meaning of variety of experiences, situations, data, events, judgments, conventions, beliefs, rules, procedures or criteria. Interpretation includes the sub-skills of categorization, decoding significance, recognition, clarifying meaning, etc. In reading, this skill includes such as identifying the author's purpose, theme or point of view, recognize the text type, summarize the main idea, etc.

The second component is analysis (Elder and Paul, 2001; Facione 2006). They state that analysis is the ability to identify the main arguments purposed by the writer. Facione (2015) defines analysis as "to identify the intended and actual inferential relationships among statements, questions, concept, descriptions, or other form of representation intended to express belief, judgments, experiences, reasons, information, or opinions". It includes examining ideas, detecting and analyzing arguments, comparing, contrasting, differentiating, and many others as the sub-skills of analysis. In the reading, the skills include such as distinguishing facts from opinions, finding arguments to support view, refining different views, etc.

The next component in critical thinking is evaluation. Evaluation is the ability to judge the credibility of argument based on the logic and evidence given. Facione (2006) adds that evaluation is assessing the credibility of statements regarding to persons' perception, experience, judgment, belief or opinion. The sub-skills include in the evaluation are concluding, comparing, discriminating, etc. In reading activity, it 
includes judging the rationality of the text, comparing authors and one's own opinion, judging if the two statements are comparing each other, etc.

The fourth component is inference (Elder and Paul, 2001; Zucker et al., 2010). They mention that inference is the ability to decide what to believe or do based on solid logic and to be aware about the result of the decision". Facione (2006) also includes inference as one of critical thinking components. He defines inference is an ability to identify and to draw reasonable conclusion, to form conjectures and hypothesis and to consider relevant information. The sub-skills of inference are conjecturing alternatives, drawing conclusions, etc. While in reading, the examples of inference are constructing meaning from the elements in reading, predicting from the title or subtitles, understanding the implicit conclusions, etc. (Putri, 2014; Jie, Yuhong and Yuan, 2014).

The next component is explanation (Elder and Paul, 2001). Explanation is the ability to inform the process of thinking or to inform the conclusion to others. Facione (2015) states that someone with explanation skill will have a strong and coherent way to present the result of one's reasoning. He adds that this skill is one of critical thinking component. It includes such as describing methods and results, justifying procedures, presenting full and well-reasoning as the sub-skills of explanation. While in reading, it includes expressing one's own opinion, writing comments according to the text, etc.

Finally, self-regulation is the sixth component of critical thinking (Elder and Paul, 2001; Facione, 2006). Self-regulation is defined as an ability to control one's own thinking and correct the wrong thing had been made. It means that monitoring one's own comprehension involve the use of cognitive skills in critical thinking (Facione, 2006). In addition, regulation involves control of one's reading to resolve the problems and increase comprehension (Hacker, 1998). The two sub-skills here are self-examination and self-correction. It includes correcting unreasonable inference, reconsidering the interpretation or judgment after reading, monitoring how well the text is comprehended, etc. In this study, the researcher uses critical thinking theory proposed by Elder and Paul, 200; Facione, 2006) to investigate the most frequent use of critical thinking skill in reading comprehension.

\section{Reading Comprehension}

Reading is the process of constructing meaning from written text through interaction with the text being read. Nunan (1989) states reading is "a complex cognitive process of decoding symbols in order to construct or derive meaning". Reading comprehension means a reader is trying to comprehend and to construct what is being read form a text (Flippo, 1999; Hollowell, 2011). Reading comprehension is often conceptualized as functioning at different levels of sophistication and referred to as literal, inferential, and critical (Westwood, 2008). According to him, the basic level of reading comprehension is literal. Meanwhile the higher level of reading comprehension is inferential and critical reading. Inferential level in this case, reader is able to go behind the words on the page and infer to other details. Further, inferential level means that the reader is 
using information effectively to deduce cause and effect, and to anticipate what will come for the next in the text. In relation to critical reading, the reader is able to appraise what he or she is reading to detect good writing style from the author, to recognize when statements in the text are biased or incorrect, to appreciate the writer's viewpoint, to contrast information with other facts they have read at other places, and to reflect on the importance or otherwise of the views presented (Westwood, 2008). Inferential requires learners to use their language skills to infer abstract information through inferring or analyzing (Zucker et al., 2010). The ultimate goal of reading is to understand, to explain, to analyze, and to criticize the meaningful information from the text (Hacker, 1998).

Mark (2004) also mentions that "the purpose of reading is to get the information, to know the content of the reading text, and to understand the meaning of the words in the text". Since information is not always directly stated in the text, readers should not only pay attention on the printed letters or words, but they should comprehend it well in order to find what the author is going to inform. Therefore, comprehension cannot be apart from reading. It means that while reading, readers put several cognitive competencies to understand the text as a way to get the information

Reading comprehension is defined as an active skill. Grellet (1981) adds that it involves guessing, predicting and asking the questions. Readers are able to predict the writer's purpose as well as the content of the text. Neil (1992) says that reading comprehension is a process that actively build meaning among the components of the text and personal experience. Readers actively participate to find the information by interacting line by line and at the same time bring their own background knowledge. From the above explanation, the researcher concludes that reading is a mental activity that needs the activation of readers' thinking to critically engage with a text and achieve comprehension. From this process, readers are able to understand and get the information intended by the writer.

Comprehension is the ability to go beyond the words, to understand the ideas in a text and the relationships that exist between those ideas (McNamara, 2007). Reader as an active information processor, and the activity of reading and the text are the important parts that work together to achieve comprehension (McIntyre, Hulan, \& Layne, 2011). As a conclusion, it can be said that reading is successfully done when comprehension is achieved.

\section{Reading strategies}

In order to understand easily the text being read, a learner should have a certain strategy in his/her mind. A good comprehend reader is characterized by detecting and resolving all problems or most of the errors. In contrast, a poor comprehend reader is demonstrated by incapable to detect and resolve the problems or most of the errors in the reading text (Hacker, 1998). Some researchers claimed that comprehension strategies as an explicitly to be taught as a reading objective (McNamara, 2007). It can 
be inferred from this statement that a reader can absorb and understand the text being read as long as he/she masters sufficient vocabulary. It comes naturally when readers read the text. However, it common found in the teaching and learning process that teachers and students learn strategies in order to understand the text. So, a reading comprehension strategy is a cognitive or behavioral action that endorsed under particular real condition with the goal of improving some aspects of comprehension (McNamara, 2007).

Generally, reading strategy is skimming and scanning. Skimming means that a reader reads the text at glance. Scanning means that a reader reads the text carefully and focuses on each paragraph in the text being read. According to Brantmeier, (2002) effective strategies in reading can be as follows; (1) reader pays most attention to what the reading passage means, (2) reader pays most attention to what the form or grammatical function of the words are, (3) reader reads the whole passage once and then rereads it, (4) reader finds the topic interesting, (5) reader thinks about what $\mathrm{s} / \mathrm{he}$ knows about the topic of the passage, (6) reader often hypothesizes about what might come text, (7) reader reads the title first and imagines what the passage might be about, and (8) reader guesses what some words mean..

\section{Method}

This study used quantitative method in nature. It involved 249 students of English Education Study Program, Faculty Teacher Training and Education, Ar-Raniry State Islamic University, Banda Aceh, Indonesia. However, the respondents of the present study consisted of 100 students from the total numbers of students. They were selected by using random sampling technique. The authors used lottery technique to select the respondents until reach 100 students from the total students. A set of questionnaire was administered to the respondents to collect the data. The questionnaire consisted of 22 statements. It used five Likert Scales namely, never, seldom, sometimes, often, and always. The authors used these scales to ensure that the frequency of using critical thinking skill among the students were right way. The critical thinking skills in this study focused on the interpretation, analysis, evaluation, inference, explanation and selfregulation. The questionnaire items used in this study was adapted from from Jie, Yuhong and Yuan (2014). The authors only changed the options scales as mentioned previously in this part. The students were given 45 minutes to answer the questionnaire. The data from questionnaire were analysed quantitatively in the form of percentage to investigate the frequencies of using critical thinking skills in reading comprehension III among students at the department.

\section{Findings}

Analysis of the findings of the current study can be reported based on the types of critical thinking skills used by students.. 
Table 1

Types of Critical Thinking Used by Students (Interpretation Skill)

\begin{tabular}{|c|c|c|c|c|c|c|}
\hline \multirow[t]{2}{*}{ No } & \multirow[t]{2}{*}{ Items } & \multicolumn{5}{|c|}{ Scales } \\
\hline & & Never & Seldom & sometimes & Often & Always \\
\hline 1 & $\begin{array}{l}\text { In daily reading, I can } \\
\text { recognize the type of the } \\
\text { reading text }\end{array}$ & $1 \%$ & $10 \%$ & $62 \%$ & $20 \%$ & $7 \%$ \\
\hline 2 & $\begin{array}{l}\text { I will pay attention to the } \\
\text { figure of speech when reading }\end{array}$ & $3 \%$ & $23 \%$ & $52 \%$ & $18 \%$ & $4 \%$ \\
\hline 3 & $\begin{array}{l}\text { I will pay attention to the } \\
\text { structure of the reading text }\end{array}$ & $4 \%$ & $21 \%$ & $56 \%$ & $14 \%$ & $5 \%$ \\
\hline 4 & $\begin{array}{l}\text { I know the writing purpose of } \\
\text { the reading text }\end{array}$ & $2 \%$ & $15 \%$ & $53 \%$ & $26 \%$ & $4 \%$ \\
\hline 5 & $\begin{array}{l}\text { I can summarize the main idea } \\
\text { of the text after reading }\end{array}$ & $2 \%$ & $16 \%$ & $54 \%$ & $22 \%$ & $6 \%$ \\
\hline & Mean & $2.4 \%$ & $17 \%$ & $55.4 \%$ & $20 \%$ & $5.2 \%$ \\
\hline
\end{tabular}

Table 1 reports the interpretation skill used by students in reading comprehension. It shows that $5.2 \%$ of students always used interpretation skill and $20 \%$ of them often used while reading. Most of the students (55.4\%) sometimes used interpretation skill while reading. it was also found that $17 \%$ of the students seldom used it while reading and $2.4 \%$ of the students never used this skill.

Table 2

Types of Critical Thinking Used by Students (Analysis Skill)

\begin{tabular}{|c|c|c|c|c|c|c|}
\hline \multirow{2}{*}{ No } & \multirow{2}{*}{ Items } & \multicolumn{5}{|c|}{ Scales } \\
\hline & & Never & Seldom & sometimes & Often & Always \\
\hline 1 & $\begin{array}{l}\text { I will pay attention to implied } \\
\text { meaning of author's mood or } \\
\text { attitue }\end{array}$ & $1 \%$ & $20 \%$ & $47 \%$ & $25 \%$ & $7 \%$ \\
\hline
\end{tabular}


2 I can distinguish facts from

$20 \%$

$44 \% \quad 26 \%$

$10 \%$ opinion

3

I can refine different views

$2 \%$

$24 \%$

$51 \%$

$20 \%$

$3 \%$

from the text when reading

4

I can find relevant arguments to

$20 \%$

$40 \%$

$23 \%$

$17 \%$

support the view of the text

Mean

$0.7 \% \quad 21 \%$

$45.5 \% \quad 23.5 \%$

$9.2 \%$

Table 2 displays the analysis skill used by students in reading comprehension. It shows that most students $(45.5 \%)$ use analysis skill sometimes. $9.2 \%$ of students always used it and $23.5 \%$ of them often use it. $21 \%$ of students seldom applied the analysis skill and $0.7 \%$ of them never used it in reading comprehension.

Table 3

Types of Critical Thinking Used by Students (Evaluation Skill)

\begin{tabular}{|c|c|c|c|c|c|c|}
\hline \multirow[t]{2}{*}{ No } & \multirow[t]{2}{*}{ Items } & \multicolumn{5}{|c|}{ Scales } \\
\hline & & Never & Seldom & Sometimes & Often & Always \\
\hline 1 & $\begin{array}{l}\text { I will judge the rationality of } \\
\text { the view from the previous } \\
\text { knowledge }\end{array}$ & $5 \%$ & $17 \%$ & $53 \%$ & $23 \%$ & $2 \%$ \\
\hline 2 & $\begin{array}{l}\text { I have my own choice and } \\
\text { judgment of the authencity of } \\
\text { information }\end{array}$ & $2 \%$ & $18 \%$ & $59 \%$ & $14 \%$ & $7 \%$ \\
\hline 3 & $\begin{array}{l}\text { I can compare my opinion with } \\
\text { that of the author in the text }\end{array}$ & $1 \%$ & $12 \%$ & $50 \%$ & $29 \%$ & $8 \%$ \\
\hline & Mean & $2.7 \%$ & $15.7 \%$ & $54 \%$ & $22 \%$ & $5.7 \%$ \\
\hline
\end{tabular}

Table 3 shows only $5.7 \%$ from them always used evaluation skill as critical thinking in reading. $22 \%$ of the students often used it in every time they read. The data also showed that many students used evaluation skill sometimes. About $54 \%$ of the students sometimes used it, $15.7 \%$ of them seldom used it and $2.7 \%$ of them never used this one in reading comprehension. 
Table 4

Types of Critical Thinking Used by Students (Inference Skill)

\begin{tabular}{|c|c|c|c|c|c|c|}
\hline \multirow{2}{*}{ No } & \multirow{2}{*}{ Items } & \multicolumn{5}{|c|}{ Scales } \\
\hline & & Never & Seldom & sometimes & Often & Always \\
\hline 1 & $\begin{array}{l}\text { I can infer the meaning of the } \\
\text { proverb from the reading text }\end{array}$ & $3 \%$ & $3 \%$ & $49 \%$ & $32 \%$ & $13 \%$ \\
\hline 2 & $\begin{array}{l}\text { I can predict the main idea of } \\
\text { reading text from title or } \\
\text { subtitle }\end{array}$ & - & $4 \%$ & $28 \%$ & $54 \%$ & $14 \%$ \\
\hline 3 & $\begin{array}{l}\text { I can speculate from various } \\
\text { clues (e.g. context) when I } \\
\text { can't understand the text }\end{array}$ & $1 \%$ & $7 \%$ & $33 \%$ & $37 \%$ & $22 \%$ \\
\hline 4 & $\begin{array}{l}\text { I can make reasonable } \\
\text { inference without reading the } \\
\text { rest of the text }\end{array}$ & $3 \%$ & $11 \%$ & $29 \%$ & $42 \%$ & $13 \%$ \\
\hline 5 & $\begin{array}{l}\text { I can understand the implicit } \\
\text { conclusion }\end{array}$ & $2 \%$ & $9 \%$ & $44 \%$ & $31 \%$ & $14 \%$ \\
\hline & Mean & $2 \%$ & $7 \%$ & $37 \%$ & $39 \%$ & $15 \%$ \\
\hline
\end{tabular}

Table 4 indicates that most of the students (39\%) often used inference skill in their reading. $15 \%$ of the students always used, $37 \%$ of students sometimes applied inference skill as critical thinking in their reading. $7 \%$ of students seldom used this skill and $2 \%$ of them never used it in the reading comprehension.

Table 5

Types of Critical Thinking Used by Students (Explanation Skill)

\begin{tabular}{|c|c|c|c|c|c|c|}
\hline \multirow[t]{2}{*}{ No } & \multirow[t]{2}{*}{ Items } & \multicolumn{5}{|c|}{ Scales } \\
\hline & & Never & Seldom & Sometimes & Often & Always \\
\hline
\end{tabular}




\begin{tabular}{lllllll}
\hline $1 \quad \begin{array}{l}\text { I can express my own opinion } \\
\text { according to the text }\end{array}$ & $3 \%$ & $10 \%$ & $48 \%$ & $29 \%$ & $10 \%$ \\
$2 \quad \begin{array}{l}\text { I can find reasonable } \\
\text { arguments in the text to support } \\
\text { my own view }\end{array}$ & $2 \%$ & $20 \%$ & $60 \%$ & $13 \%$ & $5 \%$ \\
$\begin{array}{l}\text { I can write comments on the } \\
\text { information in the text }\end{array}$ & $4 \%$ & $18 \%$ & $51 \%$ & $22 \%$ & $5 \%$ \\
\hline \\
Mean
\end{tabular}

Table 5 indicates that the percentage average of the students who always used explanation skill of critical thinking in reading was only $6.7 \%$. While, students who often used it were $21.3 \%$. More than half of students $53 \%$ sometimes used it in reading. Last, also found that $16 \%$ of students seldom practiced this skill and $3 \%$ of them found never practiced this type of critical thinking in the reading comprehension.

Table 6

Types of Critical Thinking Used by Students (Self-regulation Skill)

\begin{tabular}{|c|c|c|c|c|c|c|}
\hline \multirow[t]{2}{*}{ No } & \multirow[t]{2}{*}{ Items } & \multicolumn{5}{|c|}{ Scales } \\
\hline & & Never & Seldom & Sometimes & Often & Always \\
\hline 1 & $\begin{array}{l}\text { After reading, I can correct my } \\
\text { unreasonable inference made } \\
\text { in reading }\end{array}$ & $5 \%$ & $14 \%$ & $57 \%$ & $20 \%$ & $4 \%$ \\
\hline 2 & $\begin{array}{l}\text { I can verify my own view by } \\
\text { searching relevant material }\end{array}$ & $7 \%$ & $20 \%$ & $53 \%$ & $14 \%$ & $6 \%$ \\
\hline & Mean & $6 \%$ & $17 \%$ & $55 \%$ & $17 \%$ & $5 \%$ \\
\hline
\end{tabular}

Table 6 shows that students who always used self-regulation skill in reading were only $5 \%$. About $17 \%$ of them claim they often used this type of critical thinking. 55\% of students used self-regulation skill sometimes. $17 \%$ of the students seldom practiced it and $6 \%$ of students never applied this skill. 


\section{Conclusion, Discussion and Suggestions}

The study indicated that not all critical thinking skills are used by second year students of the department in reading comprehension III. Most of the students were frequently used inference level of critical thinking skill in reading comprehension. This finding is in line with Jie, Yuhong and Yuan, 2015; Putri, 2014). This finding showed that the level of critical thinking skills used by the students was not satisfied. Critical thinking skills are very important in reading comprehension to enable students to understand the reading text being read. Critical thinking (CT), or the ability to engage in purposeful, self-regulatory judgment, is widely recognized as an important, even essential, skill (Schafersman, 1991; Abrami et al. 2008). The students are expected to be able to use all six critical thinking in reading comprehension. However, the present study reported that the level of critical thinking skill is insufficient. The study also reported that the lower level of use of critical thinking is self-regulation. It also indicated that the students did not have good ability to develop their critical thinking skill. It is important for the teachers, lecturers, and educators to facilitate students with the critical thinking skills when teaching them in the classroom (Schafersman, 1991). By teaching students how to think critical in the reading, they will be able to understand comprehensively the information being read (Kennedy, et al., 1991)

Critical thinking is an important and vital topic in modern education. All educators are interested in teaching critical thinking to their students. Many academic departments hope that its professors and instructors will become informed about the strategy of teaching critical thinking skills, identify areas in one's courses as the proper place to emphasize and teach critical thinking, and develop and use some problems in exams that test students' critical thinking skills (Schafersman, 1991).

This study suggested that the lecturers who teach reading comprehension should facilitate and assist students to use the levels of critical thinking on the level of analysis, explanation, evaluation, interpretation, and self-regulation. "We should be teaching students how to think. Instead, we are teaching them what to think (Schafersman, 1991)." By teaching students how to think critically, they can understand easily the reading text they read. It meant that students can deal with the text being read and can understand deeply and precisely the information from the text. The authors recommended for other researchers who were interested in this study to conduct the same research that focus on other types of critical thinking skills in reading comprehension due to the current finding was limited on inferential skill that mostly used by students. This study has contributed to the indication the level of critical thinking skills that used by university students in Aceh were still in the middle level. Consequently, authorities, lecturers, practitioners, experts in teaching reading, and students should take into consideration to integrate critical thinking skills more often.

\section{References}


Abrami, P. C., Bernard, R. M., Borokhovski, E., Wade, A., Surkes, M. A., Tamim, R., \& Zhang, D. (2008). Instructional interventions affecting critical thinking skills and dispositions: A stage 1 meta-analysis. Review of Educational Research, 78(4), $1102-1134$.

Barchers, S. I. (1998). Teaching reading: From process to practice. California: Wadsworth Publishing Company.

Brantmeier, C. (2002). Second language reading strategy research at the secondary and university levels: Variations, disparities, and generalizability. The Reading Matrix, 2(3).

Burbules, N. C., \& Berk, R. (1999). Critical thinking and critical pedagogy: Relations, differences, and limits. Critical theories in education: Changing terrains of knowledge and politics, 45-65

Carr, K. S. (1988). How can we teach critical thinking?. Childhood Education, 65(2), 69-73.

Chou, P. T. (2011). The effects of vocabulary knowledge and background knowledge on reading comprehension of Taiwanese EFL students. Electronic Journal of Foreign Language Teaching, 8(1), 108-115.

Choy, S. C., \& Cheah, P. K. (2009). Teacher perceptions of critical thinking among students and its influence on higher education. International Journal of Teaching and Learning in Higher Education, 20(2), 198-206.

Cottrell, S. (2011). Critical thinking skills: Developing effective analysis and argument. Palgrave Macmillan.

Duron, R., Limbach, B. \& Waugh, W. (2006). Critical thinking framework for any discipline. International Journal in Teaching and Learning in Higher Education, 17(2), 160-166.

Elder, L., \& Paul, R. (2001). Thinking to some purpose. Journal of Developmental Education, 25(1), 40-41.

Facione, A. P. (2006). Critical thinking: What it is and why it counts. California: California Academic Press.

Facione, A. P. (2015). Critical thinking: What it is and why it counts. Retrieved December

25 , 2015

from 
http://www.student.uwa.edu.au/_data/assets/pdf_file/0003/1922502/CriticalThinking-What-it-is-and-why-it-counts.pdf.

Flippo, R. F. (1999). What Do the Experts Say?: Helping Children Learn to Read. Heinemann.

Grellet, F. (1981). Developing reading skills: A practical guide to reading comprehension exercises. Cambridge: Cam bridge University Press.

Hacker, D. J. (1998). Self-regulated comprehension during normal reading. Metacognition in educational theory and practice, 165-191.

Halpern, D. F. (1999). Teaching for critical thinking: Helping college students develop the skills and dispositions of a critical thinker. New Directions for Teaching and Learning, 80, 69-74.

Halpern, D. F. (2002). Thought and knowledge: An introduction to critical thinking. Routledge.

Hollowell, K. (2011). Kinds of Reading, accessed from http://www.ehow.com/list_6604712_kinds-reading-skills.html, on September 15th, 2011

Jie, Z., Yuhong, J., \& Yuan, Y. (2014). The investigation on critical thinking ability in EFL reading class. English Language Teaching, 8(1), 1-12.

Kamali, Z., \& Fahim M. (2011). The relationship between critical thinking ability of Iranian EFL learners and their resilience level facing unfamiliar vocabulary items in reading. Journal of Language Teaching and Research. 2(1), 104-111.

Kennedy, M., Fisher, M. B., \& Ennis, R. H. (1991). Critical thinking: Literature review and needed research. Educational values and cognitive instruction: Implications for reform, 2, 11-40.

Mark, S. (2004). Conceptual foundation of teaching reading. New York: The Guildford Press.

McIntyre, E., Hulan, N., \& Layne, V. (2011). Reading instruction for diverse classrooms. New York: The Guilford Press.

McNamara, D. S. (2007). Reading comprehension strategies: Theories, interventions and technologies. Mahwah: Lawrence Erlbaum Associates.

McPeck, J. E. (2016). Critical thinking and education. Routledge. 
Neil, J. D. (1992). Reading comprehension: New direction for classroom practice. New York: Harper Collins Publisher.

Nunan, D. (1999). Designing task for communicative classroom. Cambridge: Cambridge University Press.

Paul, R. W. (1985). Bloom's taxonomy and critical thinking intervention. Educational Leadership, 42(8), 36-39.

Paul, R. (1992). Critical thinking: What, why, and how. New directions for community colleges, 1992(77), 3-24.

Petress, K. (2004). Critical thinking: An extended definition. Education, 124(3), 461.

Pressley, M. (2006). Reading instruction that works: The case for balanced teaching. New York:Guilford Press.

Putri, O. (2014). Investigating junior high school students' critical thinking in reading. (Unpublished Thesis). Universitas Pendidikan Indonesia, Bandung.

Schultz, R. A. (1982). Literature and readability: Bridging the gap in foreign language. Modern Language Journal, 20(4), 43-53.

Schafersman, S. D. (1991). An introduction to critical thinking. Retrieved March, 5, 2008.

Westwood, P. (2008). What Teachers Need to Know about Reading and writing Difficulties, (FirstEdition, Australia, Acer Press, 2008), p. 32

Zabihi, R., \& Pordel, M. (2011). An investigation of critical reading in reading textbooks: A qualitative analysis. International Education Studies, 4(3), 1-8

Zucker, T. A., Justice, L. M., Piasta, S. B., \& Kaderavek, J. N. (2010). Preschool teachers' literal and inferential questions and children's responses during whole-class shared reading. Early Childhood Research Quarterly, 25(1), 65-83 